\title{
PENGARUH PEMBERIAN MULTIVITAMIN PADA PAKAN TERHADAP PERTUMBUHAN DAN KELANGSUNGAN HIDUP IKAN PATIN (Pangasius pangasius)
}

\author{
Ahmad Khabib Ulin Nuha', Andi Rahmad Rahim², Aminin ${ }^{2}$ \\ ${ }^{1}$ Mahasiswa Prodi Akuakultur, Fakultas Pertanian Universitas Muhammadiyah Gresik \\ ${ }^{2}$ Dosen Prodi Akuakultur, Fakultas Pertanian Universitas Muhammadiyah Gresik \\ E-mail : Arofah.lin37@ gmail.com ; Phone : 088235823313
}

\begin{abstract}
As one of fish commodity, Catfish (Pangasius pangasius) has a very important economic value for the community. The time needed for catfish cultivation tends to be long and the price of feed is high so that it triggers the less optimal production of catfish. One way to maximize good production and with minimized time is by adding multivitamin probiotics to the feed. This research aims to analyze the optimal dose of probiotics to the growth and survival rate of catfish . Method used is Complete Randomized Design Design (CRDD) using 4 treatments of probiotic doses and 3 replicates. The treatments are A Control $(0.00 \mathrm{ml} / \mathrm{kg})$, B (10 ml/kg), C (15 ml/kg), and D (20 ml/kg). Absolute weight, absolute length, and survival of catfish are the main variables observed. The data were analyzed by using the analysis of variance and continued with the LSD test (the Least Significant Difference), $\alpha=0.05$. The optimal dose of probiotics based on the absolute length and absolute weight of catfish is 10 $\mathrm{ml} / \mathrm{kg}$ and it produces an absolute weight of 5.27 gram and absolute length of $5.76 \mathrm{~cm}$. The optimal daily specific growth rate is at the probiotics dose of $10 \mathrm{ml} / \mathrm{kg}$ which is $2.302 .55 \% /$ day. The highest survival rate for catfish is $100 \%$ at probiotic doses of 0.000 $\mathrm{ml} / \mathrm{kg}, 10 \mathrm{ml} / \mathrm{kg}$ and $15 \mathrm{ml} / \mathrm{kg}$. The range of water quality is in the temperature of $27.5-$ $28,9^{\circ} \mathrm{C}, \mathrm{pH} 6.79$ - 7.88, DO 6.4 - $7.9 \mathrm{ppm}$, and ammonia 0 ppm.
\end{abstract}

Keywords: Probiotics, Catfish, Growth Rate, Survival

\begin{abstract}
ABSTRAK
Ikan patin (Pangasius pangasius) sebagai komoditas ikan mempunyai nilai ekonomi yang sangat penting bagi masyarakat. Waktu yang di butuhkan untuk budidaya ikan patin cenderung lama dan harga pakan yang relatif tinggi menjadi pemicu kurang optimalnya produksi ikan patin. Salah satu cara memaksimalkan hasil produksi yang baik dan dengan waktu yang bisa diminimalisir adalah dengan penambahan probiotik multivitamin pada pakan. Penelitian ini bertujuan menganalisis dosis optimal probiotik terhadap laju pertumbuhan dan kelangsungan hidup ikan patin. Rancangan Acak Lengkap (RAL) dengan 4 perlakuan dan 3 ulangan sebagai metode dalam penelitian ini. Penambahan dosis probiotik A Kontrol $(0 \mathrm{ml} / \mathrm{kg})$, B $(10 \mathrm{ml} / \mathrm{kg})$, C $(15 \mathrm{ml} / \mathrm{kg})$, dan D (20 ml/l) sebagai perlakuan. Bobot mutlak, panjang mutlak, dan kelangsungan hidup ikan patin sebagai variabel utama yang diamati. Kualitas air sebagai variabel penunjang. Data dianalisis dengan Analysis Of Varian (ANOVA) kemudian dilanjutkan dengan uji BNT (Beda Nyata Terkecil) 0,05. Dosis optimal probiotik berdasarkan bobot mutlak dan panjang mutlak ikan patin adalah $10 \mathrm{ml} / \mathrm{kg}$ dan
\end{abstract}


menghasilkan bobot mutlak 5,27 g dan panjang $5,76 \mathrm{~cm}$. Laju spesifik pertumbuhan harian yang optimal adalah pada dosis probiotik $10 \mathrm{ml} / \mathrm{kg}$ yaitu 2,30-2,55 \%/hari, Kelangsungan hidup ikan patin tertinggi adalah $100 \%$ pada dosis probiotik $0 \mathrm{ml} / \mathrm{kg}, 10 \mathrm{ml} / \mathrm{kg}$, dan $15 \mathrm{ml} / \mathrm{kg}$. Kisaran kualitas air yaitu suhu $27,5-28,9^{0} \mathrm{C}$, pH 6,79-7,88, DO 6,4 - 7,9 ppm, ammonia 0 ppm.

Kata Kunci : Probiotik, Ikan Patin, Laju Pertumbuhan, Kelangsungan Hidup.

\section{PENDAHULUAN}

Ikan patin merupakan salah satu jenis ikan air tawar yang memiliki nilai ekonomis tinggi dan juga merupakan ikan konsumsi yang digemari oleh konsumen. Permintaan pasar terhadap ikan patin dari tahun 2007 hingga sekarang terus meningkat, tidak hanya dari pasar domestik melainkan juga pasar mancanegara, sehingga ikan patin mempunyai prospek yang sangat baik dalam pemasaran. Namun, permintaan pasar yang kian hari kian meningkat ini juga harus didukung oleh kualitas dan kuantitas benih yang baik pula. Untuk meningkatkan kualitas adalah dengan pemberian multivitamin pada pakan.

Bahan bahan yang biasa digunakan sebagai suplemen tambahan pada pakan diantaranya adalah vitamin $\mathrm{C}$, vitamin $\mathrm{E}$, probiotik, serta kayu manis. Bahan-bahan tersebut termasuk jenis organic additive. Makatutu (2002) menggunakan vitamin C dan vitamin E dalam pakan untuk memacu perkembangan gonad dan meningkatkan mutu telur ikan kerapu batik, Jusadi et al., (2004) menambahkan probiotik (Bacillus sp.) dalam pakan komersil ikan patin menghasilkan peningkatkan laju pertumbuhan harian ikan dan penurunan konversi pakan.

Multivitamin probiotik dipakai di dalam budidaya ikan patin dengan cara di aplikasikan pada pakan dengan dosis tertentu untuk memacu pertumbuhan ikan dan menjaga kelangsungan hidupnya. Pemberian multivitamin probiotik tersebut di harapkan mampu merasuk di dalam saluran pencernaan ikan patin sehingga dapat memaksimalkan kemampuan ikan dalam mencerna pakan. Secara komersial, multivitamin probiotik banyak di produksi untuk ikan air tawar. Tetapi karena banyaknya spesies ikan budidaya dan memiliki kebiasaan makan yang berbeda beda serta kemampuan memproduksi enzim pencernaan, maka perlu adanya penelitian terkait dengan efektivitas multivitamin probiotik tersebut.

\section{TINJAUAN PUSTAKA}

Ikan patin (Pangasius sp.) adalah salah satu ikan asli perairan Indonesia yang telah berhasil didomestikasi. Jenis-jenis ikan patin di Indonesia sangat banyak, antara lain Pangasius pangasius, Pangasius humeralis, Pangasius lithostoma, Pangasius nasutus, pangasius polyuranodon, Pangasius niewenhuisii. Sedangkan Pangasius sutchi dan Pangasius hypophtalmus yang dikenal sebagai jambal siam atau lele bangkok merupakan ikan introduksi dari Thailand (Kordi, 2005).

Ikan patin mempunyai bentuk tubuh memanjang, berwarna putih perak dengan punggung berwarna kebiruan. Ikan patin tidak memiliki sisik, kepala ikan patin relatif kecil 
dengan mulut terletak diujung kepala agak ke bawah. Hal ini merupakan ciri khas golongan catfish. Panjang tubuhnya dapat mencapai $120 \mathrm{~cm}$. Sudut mulutnya terdapat dua pasang kumis pendek yang berfungsi sebagai peraba. Sirip punggung memiliki sebuah jari-jari keras yang berubah menjadi patil yang besar dan bergerigi di belakangnya, sedangkan jari-jari lunak pada sirip punggungnya terdapat $6-7$ buah (Kordi, 2005).

Pada permukaan punggung terdapat sirip lemak yang ukurannya sangat kecil dan sirip ekornya membentuk cagak dengan bentuk simetris. Sirip duburnya agak panjang dan mempunyai 30 - 33 jari-jari lunak, sirip perutnya terdapat 6 jari-jari lunak. Sedangkan sirip dada terdapat sebuah jari-jari keras yang berubah menjadi 6 senjata yang dikenal sebagai patil dan memiliki 12 - 13 jari-jari lunak (Susanto dan Khairul, 1996).

\section{METODOLOGI}

Penelitian ini dilaksanakan di media wadah plastik di Desa Kandangan Kecamatan Cerme Kabupaten Gresik. Alat yang di gunakan dalam penelitian ini adalah ember plastik, seser, aerator, timbangan analitik, dan pengggaris. Serta alat ukur kualitas air DO meter, $\mathrm{pH}$ meter, dan Amoniak teskit. Bahan yang di gunakan ikan patin ukuran $7-10 \mathrm{~cm}$ yang di dapatkan dari Desa Pandaan, Kecamatan Duduk, Kabupaten Gresik dan multivitamin boster vitaliquid.

Rancangan percobaan yang digunakan dalam penelitian ini adalah rancangaan acak lengkap (RAL). Penelitian ini dilakukan dengan 4 perlakuan dan 3 kali ulangan dengan susunan perlakuan sebagai berikut :

$\mathrm{A}=\operatorname{Kontrol}(0 \mathrm{ml} / \mathrm{kg}$ pakan$)$

$\mathrm{B}=10 \mathrm{ml} / \mathrm{kg}$ pakan

$\mathrm{C}=15 \mathrm{ml} / \mathrm{kg}$ pakan

$\mathrm{D}=20 \mathrm{ml} / \mathrm{kg}$ pakan

$1,2,3=$ ulangan

Persiapan di mulai dari wadah dibersihkan dan dijemur untuk menghilangkan bibit penyakit. Kemudian masing-masing wadah diberi label. Selanjutnya dilakukan pemasangan alat-alat kelengkapan seperti pemasangan aerator untuk aerasi atau penambahan oksigen pada masing-masing wadah. Sebelum ditebar, benih ikan patin diukur panjang awal dan ditimbang bobot awal. Kemudian benih ikan ditebar sebanyak 10 ekor untuk tiap wadah dengan di aklimatisasi dahulu. Pakan diberikan tiga kali sehari yaitu pagi, siang dan sore hari, dengan dosis pakan $4 \%$ dari bobot tubuh ikan. Pakan yang digunakan pada penelitian ini adalah PF 500 komposisi protein $(\min ) 30 \%$, lemak $(\min ) 5 \%$, serat kasar $(\max ) 6 \%$, abu $(\max ) 16 \%$, kadar air $(\max ) 10 \%$. Sebelum pakan di berikan, terlebih dahulu di berikan penmbahan multivitamin probiotik dengan dosis yang berbeda sesuai perlakuan pada penelitian. 
ISSN : 2615-1537

E-ISSN : 2615-2371

\section{HASIL DAN PEMBAHASAN}

\section{Pertumbuhan Ikan Patin}

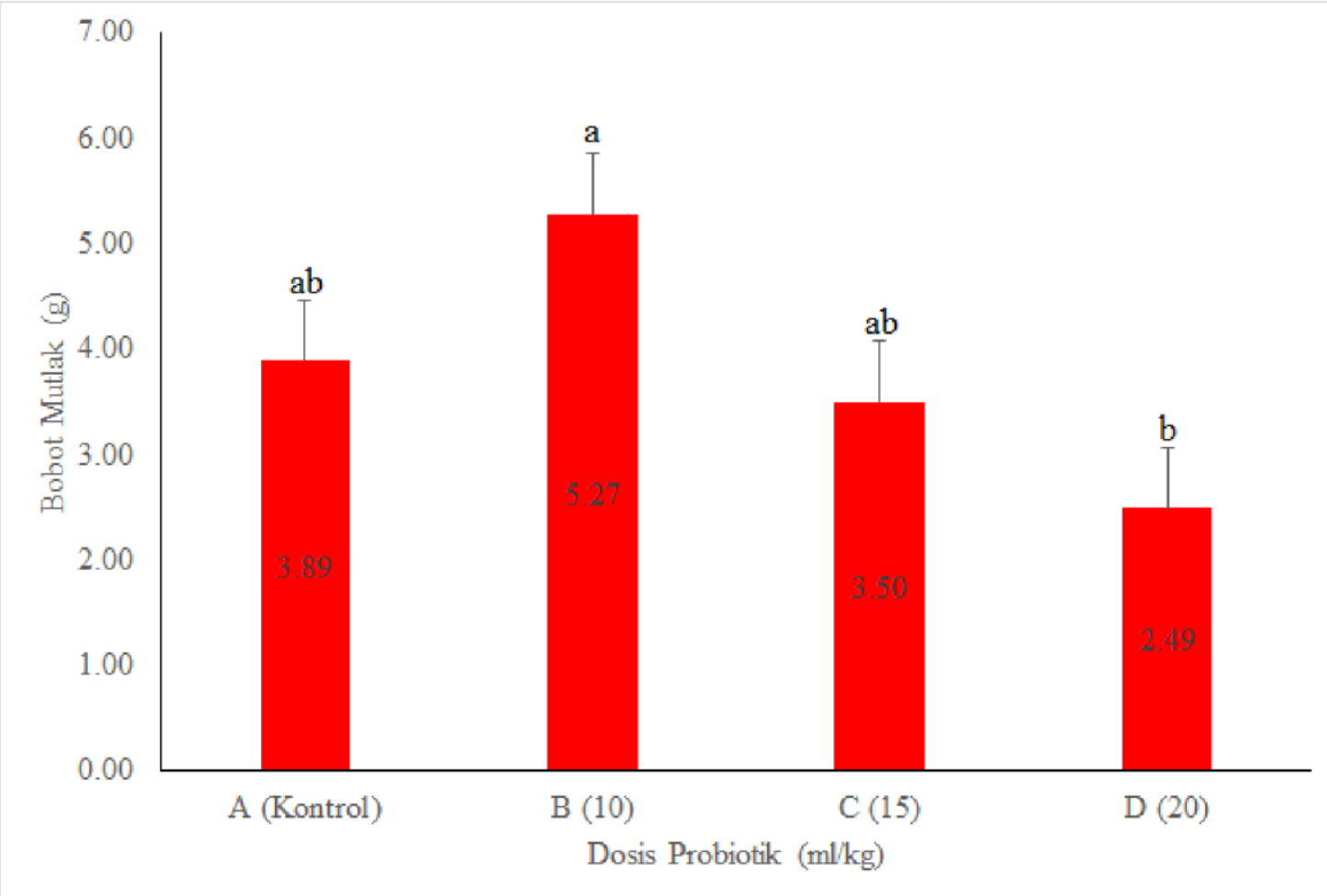

Gambar 1. Histogram Bobot Mutlak Ikan Patin (Pangasius pangasius).

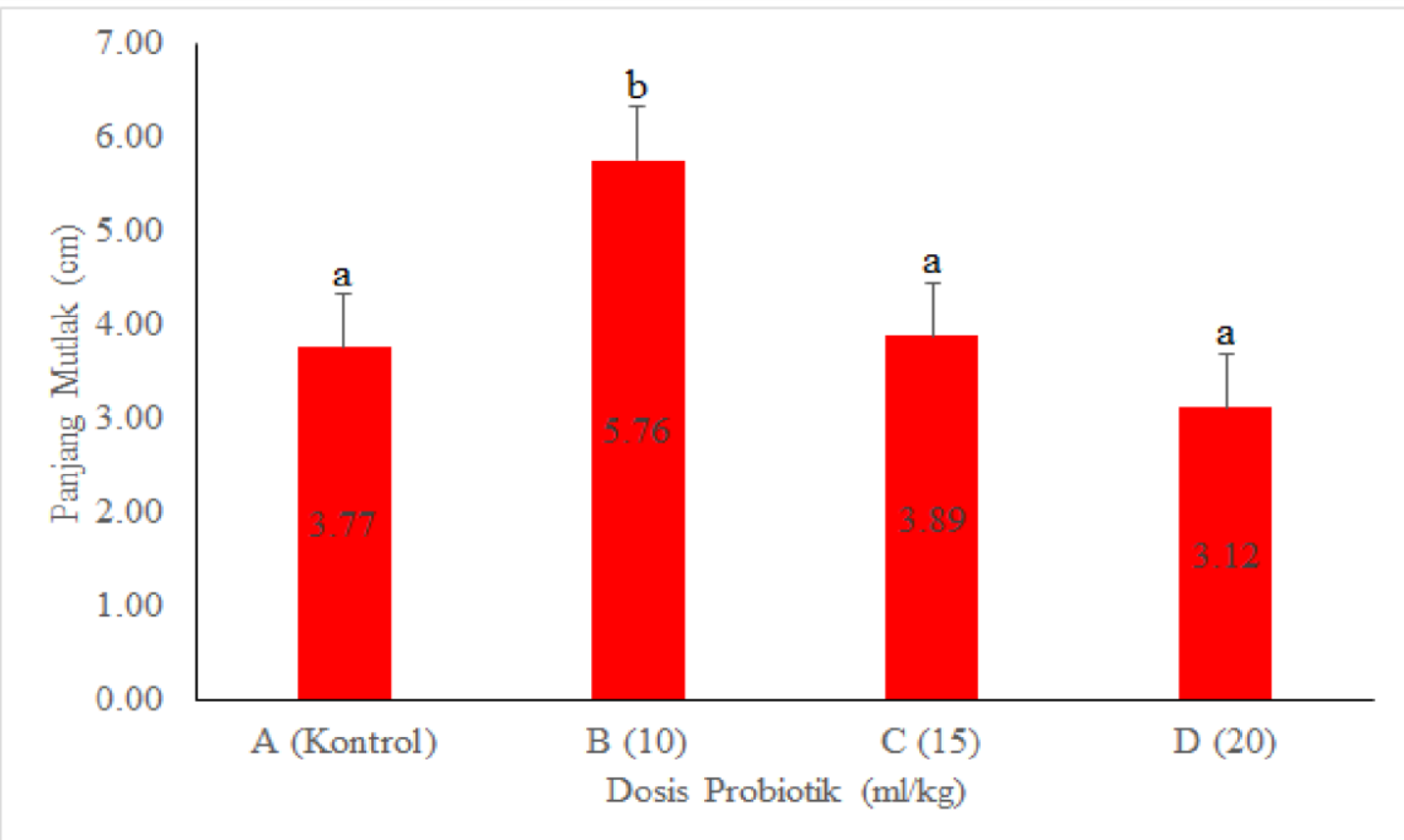

Gambar 2. Histogram Panjang Mutlak Ikan Patin (Pangasius pangasius). 
Gambar 1. Rata-rata Bobot Mutlak Ikan Patin.dari Gambar di atas menunjukkan, ratarata bobot mutlak ikan patin selama penelitian dengan kisaran yaitu 2,49 - 5,27 g. Dengan perlakuan tertinggi didapatkan pada perlakuan B $(10 \mathrm{ml} / \mathrm{kg})$ dan terendah pada perlakuan D (20 ml/kg). Menurut pendapat NRC (1983) dalam Beauty et. al., (2012), bahwa apabila pemberian pakan sudah optimal maka energi yang diperlukan untuk pemeliharaan tubuh dan aktivitas harian telah terpenuhi maka energi tersebut akan digunakan untuk pertumbuhan.

Gambar 2. Rata-rata Panjang Mutlak Ikan Patin dari gambar di atas menunjukkan rata rata laju pertumbuhan panjang mutlak ikan patin dengan kisaran yaitu 3,12-5,76 cm. bahwa perlakuan B $(10 \mathrm{ml} / \mathrm{kg})$ memberikan perbedaan yang nyata terhadap perlakuan A (Kontrol), C $(15 \mathrm{ml} / \mathrm{kg})$ dan $\mathrm{D}(20 \mathrm{ml} / \mathrm{kg})(\mathrm{p}<0,05)$, kemudian tidak memberikan perbedaan yang nyata dengan perlakuan A (Kontrol), C (15 ml/kg), dan D $(20 \mathrm{ml} / \mathrm{kg})$ pada masing-masing perlakuan $(\mathrm{p}>0,05)$. Pertumbuhan terjadi karena kelebihan energi dan asam amino (protein) yang berasal dari pakan. Energi tersebut digunakan untuk metabolisme, gerak, dan mengganti sel-sel yang rusak. Pertumbuhan meningkat jika pakan dapat dicerna dengan baik, sehingga menjadi energi yang dapat dimanfaatkan secara optimal oleh ikan. Penambahan probiotik dapat memperbaiki sistem pencernaan ikan sehingga mampu meningkatkan laju pertumbuhan secara optimal (Fitriyah, 2017).

\section{Laju Pertumbuhan Spesifik Harian (\%/Hari)}

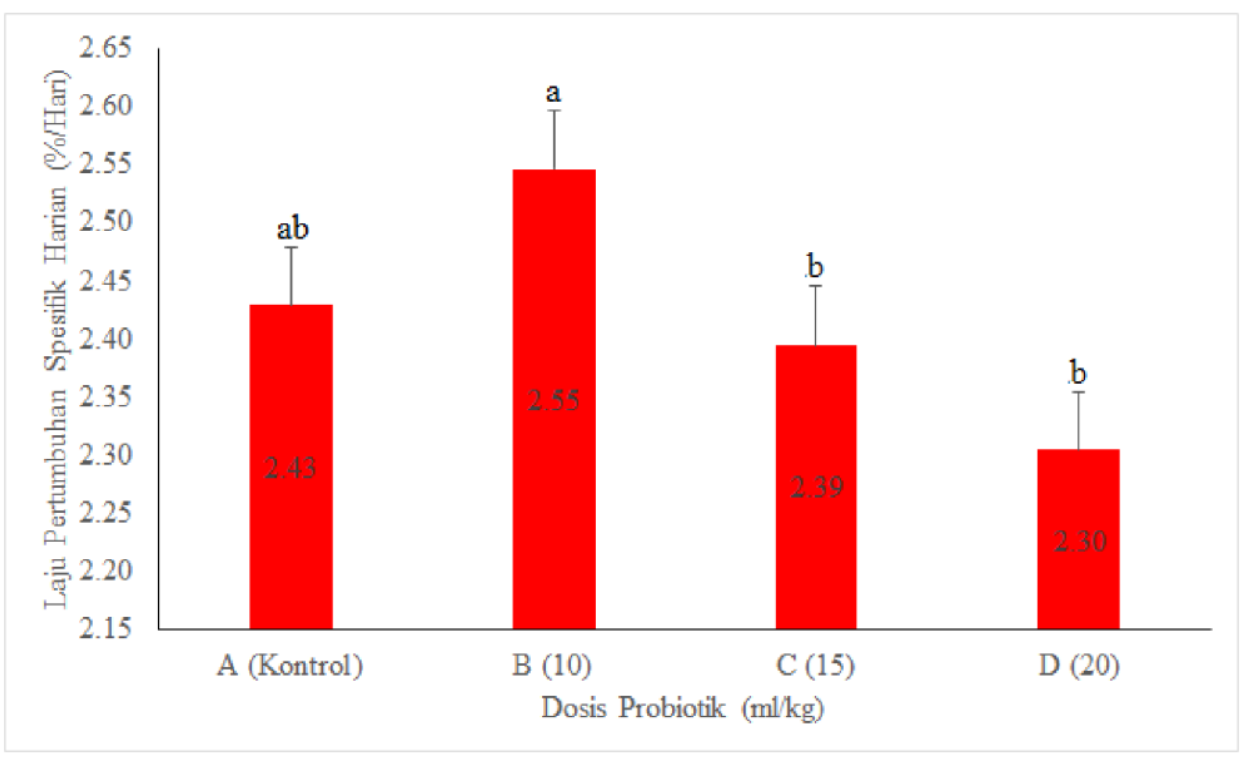

Gambar 3. Rata-rata Laju Pertumbuhan Spesifik Harian Ikan Patin .

Dari gambar di atas menunjukkan rata rata laju pertumbuhan harian ikan patin dengan kisaran yaitu 2,30-2,55 \%/hari. Perlakuan B (10 ml/kg) memberikan perbedaan yang nyata terhadap perlakuan $\mathrm{C}(15 \mathrm{ml} / \mathrm{kg})$ dan $\mathrm{D}(20 \mathrm{ml} / \mathrm{kg})(\mathrm{p}<0,05)$, kemudian tidak memberikan perbedaan yang nyata dengan perlakuan A (Kontrol) $(\mathrm{p}>0,05)$. Sedangkan perlakuan A (Kontrol), C ( $15 \mathrm{ml} / \mathrm{kg})$ dan $\mathrm{D}(20 \mathrm{ml} / \mathrm{kg})$ tidak memberikan perbedaan yang nyata pada masing-masing perlakuan ( $\mathrm{p}>0,05)$. 
Hal ini diduga energi pakan yang diberikan pada ikan patin cukup sehingga kebutuhan energi untuk metabolisme cukup dan dapat digunakan untuk tumbuh. Lebih lanjut penambahan probiotik pada pakan juga turut membantu proses pencernaan dengan baik sehingga mampu digunakan ikan untuk tumbuh dengan baik. Hal ini sesuai dengan pernyataan Sabariah (2010) yang menyatakan bahwa penambahan probiotik pada pakan dapat meningkatkan laju perumbuhan ikan patin.

\section{Kelangsungan Hidup (\%)}

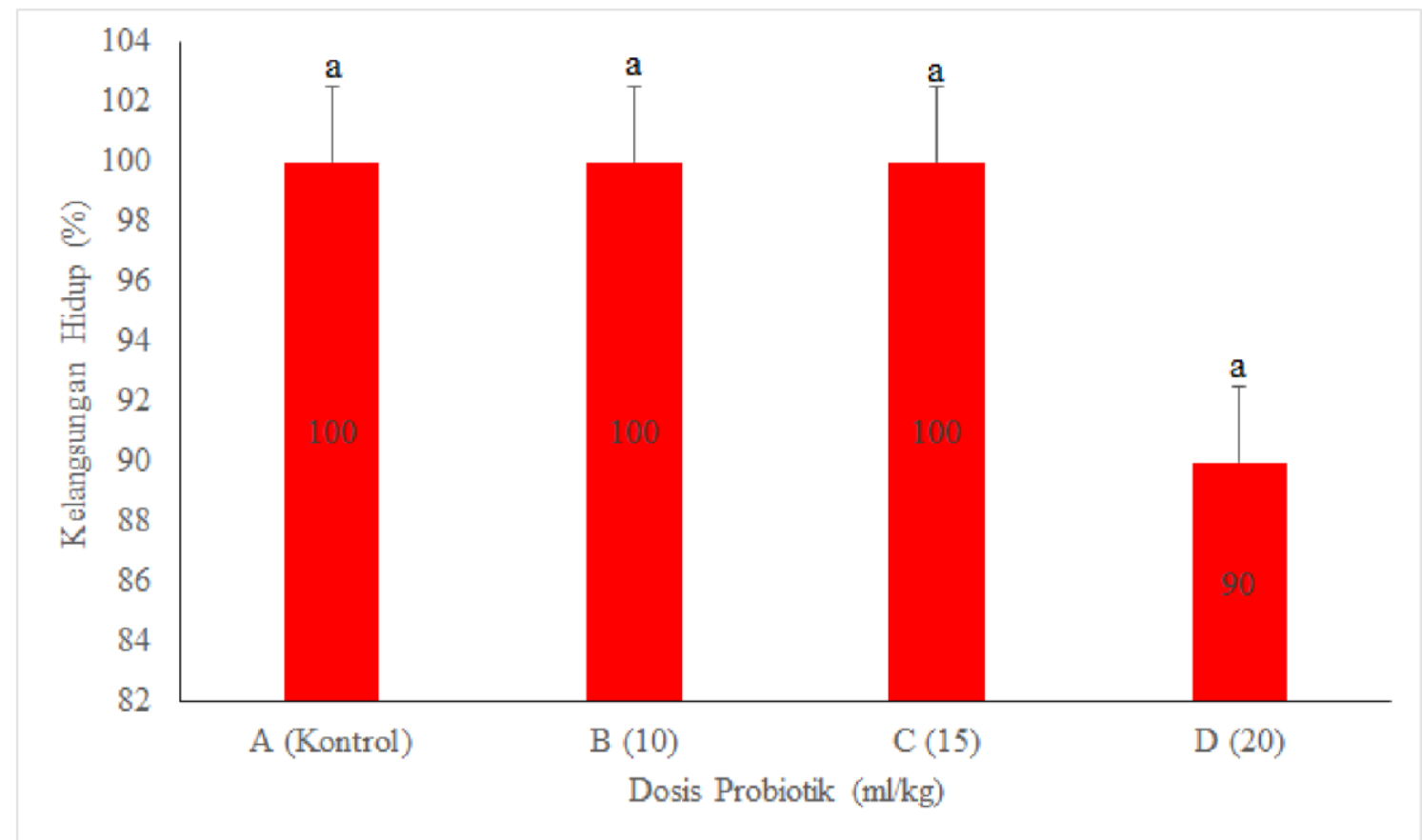

Gambar 4. Rata-rata Kelangsungan Hidup Ikan Patin .

Dari gambar di atas menunjukkan rata-rata kelangsungan hidup ikan patin dengan kisaran yaitu 90-100 \%. Pemberian dosis probiotik tidak memberikan pengaruh yang nyata atau non signifikan terhadap peningkatan kelangsungan hidup ikan patin ( $p>0,05)$. Kematian ikan selama penelitian disebabkan pada saat sampling ikan mengalami stres sehingga ikan tidak semuanya mampu bertahan hidup sampai minggu terakhir penelitian. Selain itu juga disebabkan karena kemampuan ikan berbeda dalam beradaptasi terhadap lingkungan. Hal inilah yang menyebabkan kelulus hidupan ikan menjadi bervariasi pada setiap perlakuan.

Tingkat kelangsungan hidup ikan selama penelitian tergolong baik hal ini sesuai dengan pernyataan yang dinyatakan oleh Husen (1985) dalam Simangunsong (2017) bahwa tingkat kelangsungan hidup $\geq 50 \%$ tergolong baik, kelangsungan hidup 30-50\% sedang dan kelangsungan hidup kurang dari 30\% tidak baik. Menurut Fatimah (1992) dalam Simangunsong (2017) bahwa kelangsungan hidup ikan sangat bergantung pada daya adaptasi ikan terhadap makanan dan lingkungan, status kesehatan ikan, padat tebar, dan kualitas air. 


\section{Rasio Konversi Pakan (FCR)}

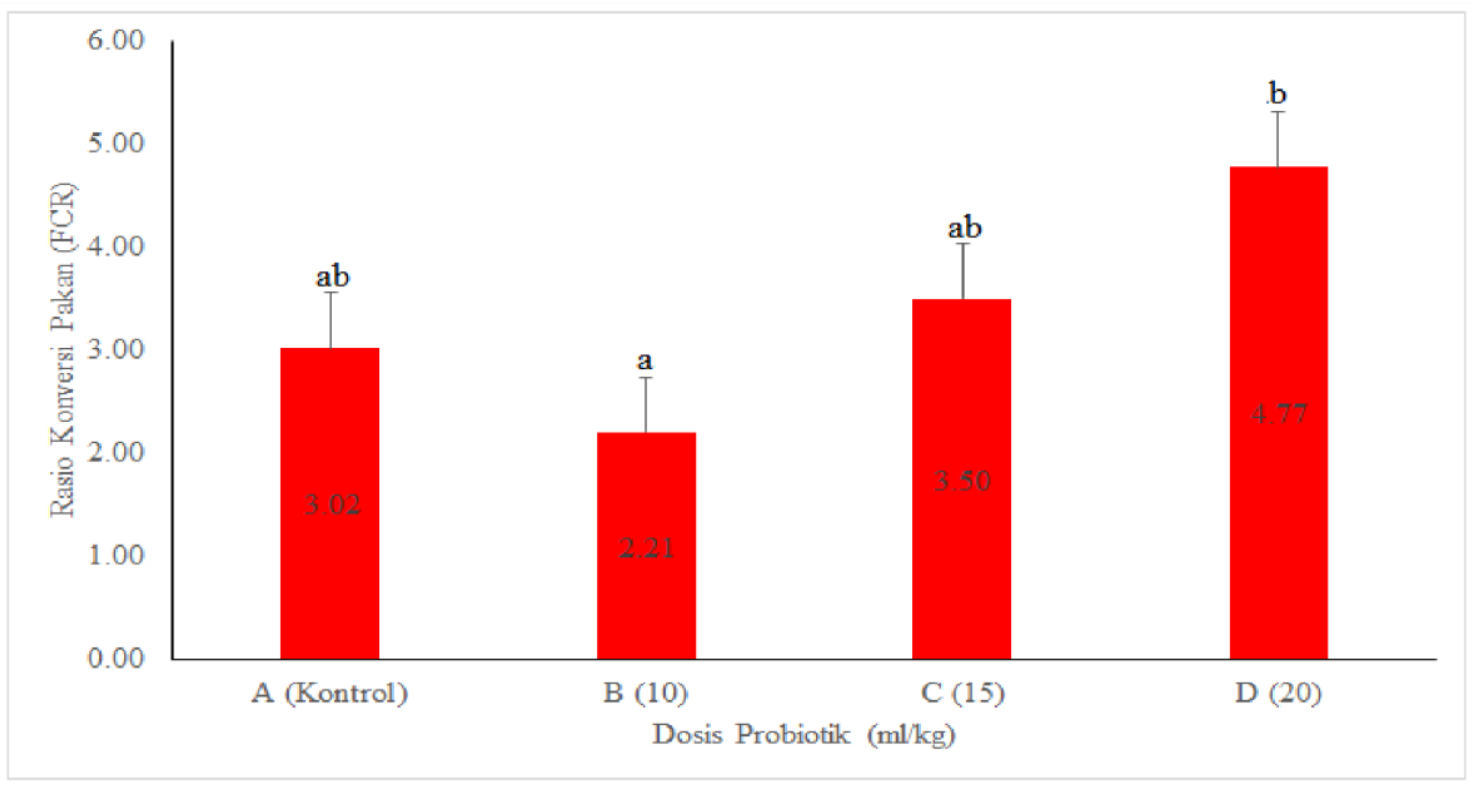

Gambar 5. Rasio Konversi Pakan Ikan Patin.

Dari gambar di atas menunjukkan rata-rata Rasio Konversi Pakan ikan patin dengan kisaran yaitu 2,21-4,77. Pemberian dosis probiotik memberikan pengaruh yang nyata atau signifikan terhadap penurunan nilai Rasio Konversi Pakan ikan patin $(\mathrm{p}<0,05)$. Perlakuan B $(10 \mathrm{ml} / \mathrm{kg})$ memberikan perbedaan yang nyata terhadap perlakuan $\mathrm{D}(20 \mathrm{ml} / \mathrm{kg})(\mathrm{p}<0,05)$, kemudian tidak memberikan perbedaan yang nyata dengan perlakuan A (Kontrol) dan C $(15 \mathrm{ml} / \mathrm{kg})(\mathrm{p}>0,05)$. Sedangkan perlakuan A (Kontrol), C (15 ml $/ \mathrm{kg})$ dan D $(20 \mathrm{ml} / \mathrm{kg})$ tidak memberikan perbedaan yang nyata pada masing-masing perlakuan $(\mathrm{p}>0,05)$. Djajasewaka (1986) dalam Santoso dan Veroka (2011) menyatakan bahwa nilai efisiensi pakan berbanding terbalik dengan konversi pakan dan berbanding lurus dengan pertambahan berat tubuh ikan, sehingga semakin tinggi nilai efisiensi pakan maka nilai koversi pakan semakin rendah sehingga ikan semakin efisien memanfaatkan pakan yang dikonsumsi untuk pertumbuhan.

\section{KESIMPULAN DAN SARAN}

Hasil penelitian dapat disimpulkan bahwa Perlakuan dosis probiotik pada pakan menunjukkan perbedaan nyata terhadap laju pertumbuhan ikan patin. Berdasarkan bobot mutlak dan panjang mutlak ikan patin, nilai optimal dosis probiotik adalah $10 \mathrm{ml} / \mathrm{Kg}$. Perlakuan dosis probiotik pada pakan tidak menunjukkan perbedaan nyata terhadap kelangsungan hidup ikan patin.

Para pembudidaya ikan patin diharapkan mengoptimalkan penggunaan probiotik untuk memperoleh hasil yang maksimal. Selanjutnya diharapkan melanjutkan penelitian yang lebih mendalam. Hal itu bertujuan untuk mencari titik optimal dosis probiotik yang dapat menghasilkan laju pertumbuhan yang lebih maksimal dan survival rate ikan patin yang baik. 


\section{UCAPAN TERIMA KASIH}

Terima kasih disampaikan kepada seluruh pihak yang terlibat dalam penelitian ini. Terutama kepada Dosen pembimbing Dr. Andi Rahmad Rahim,S.Pi,.Msi dan Aminin S.Pi,.MP serta seluruh Dosen Program Studi Akuakultur, Juga kepada teman teman Program Studi Akuakultur terutama angkatan 2015 yang telah banyak membantu dalam segala hal.

\section{DAFTAR PUSTAKA}

Temalem. G. 2001. Analisis Kelayakan Investasi Usaha Pembenihan Ikan Patin di Tapos Agro Lestari. Skripsi. Institut Pertanian Bogor.

Atira. 2009. Pengaruh Berbagai Kosentrasi Inokulum Lactobacillus plantarum Terhadap Tingkat Kelangsungan Hidup Ikan Patin (Pangasius hypophthalmus). Universitas Tadulako

Alamsyah. S. 2011. Pengaruh Feed Additif Mikrob Bacillus sp dan Carnobacterium sp Pada

Kadar Glukosa Darah Dan Laju Metabolisme Serta Neraca Energi Ikan Gurame (Osphronemus gouramy Lac.) Fase Omnivora. Riau

Effendie, M. I. 1979. Metode Biologi Perikanan. Yayasan Dewi Sri. Bogor.

Gandara. E. 2004. Pengaruh Penambahan Probiotik Bacillus sp Pada Pakan Komersil Terhadap Konversi Pakan dan pertumbuhan Ikan Patin. Jurnal Akuakultur Indonesia. Bogor.

Gaspers V., 1995. Tehnik Analisis Dalam Penelitian Percobaan. Tarsito. Bandung.

Kusriningrum, et al. 2008. Pengaruh Penambahan Probiotik Pada Paka Buatan Terhadap Pertumbuhan Dan Rasio Konversi Pakan Ikan Nila Gift (Oreochromis niloticus). Berkala Ilmiah Perikanan. Universitas Airlangga.

Laksmiwati, Ni Made. 2009. Pengaruh Pemberian Starbio Dan Effective Microorganisme- 4 ( EM-4) Sebagai Probiotik Terhadap Penampilan Itik Jantan Umur $0-8$ Minggu. Skripsi. Jurusan Produksi Ternak, Fakultas Peternakan, Universitas Udayana, Denpasar

Maesaroh, E. 2004. Berbagai Tingkat pemberian Pakan Pada Ikan Patin (Pangasius hypophthalmus) Dalam Karamba di Sungai Ciomas. Bogor. Skripsi. IPB. 19 hal.

Mahyuddin. K. 2010. Paduan Lengkap Agribisnis Patin . Penebar Swadaya, Anggota Ikapi. Jakarta. 6-3 hal.

Malik Tangko, A dan Abdul, M. 2008. Probiotik: Pemanfaatannya Untuk Pakan Ikan Berkualitas Rendah. Balai Riset Perikanan Budidaya Air Payau. Maros. 146 hal.

Nurbaya. 2010. Pengaruh Perbedaan Waktu Aplikasi Probiotik Terhadap Kualitas Dan Sintasan Pasca Larva Udang Windu (Penaeus monodon). Balai Riset Perikanan Budidaya Air Payau. Sulawesi Selatan

Puput, 2010. Program Kreatifitas Mahasiswa Efektifitas Penggunaan Probiotik Untuk Menghindari Investasi Argulus sp Pada Ikan Mas (Cyprinus carpio). Surabaya 
ISSN : 2615-1537

E-ISSN : 2615-2371

Rahmawati, R., Septyan, A., dan Nurbakti, A. 2010. Pengaruh Pemberian Probiotik Dengan Dosis Yang Berbeda Terhadap Sintasan Dan Pertumbuhan Benih Patin Djambal (Pangasius djambal). Balai Riset Perikanan Budidaya Laut. Gondol. 